\title{
Performance of Eight Cowpea (Vigna unguiculata) Cultivars on an Oxisol in Northwestern Puerto Rico'
}

\author{
José Badillo-Feliciano and Raúl Abrams ${ }^{2}$
}

\begin{abstract}
Eight cowpea cultivars were evaluated for three years on the basis of yield and adaptability to the climatic conditions prevailing in northwestern Puerto Rico. Tests were conducted on a Coto clay (Oxisol) at the Isabela Substation, Puerto Rico. The cultivars tested were the brown-colored B 54; the black "eye" peas Pequeño, Costa Rica and Frijol Gordo; the black cowpea Centa 105; and the cream-colored cultivars Climax, Sin Fibra and Zipper Cream. Maximum mean adjusted yield of $2197 \mathrm{~kg} / \mathrm{ha}$ over three crops, were obtained from cv. B 54. The black "eye" pea cvs. Pequeño, Costa Rica and Frijol Gordo yielded 2066, 1960, and $1743 \mathrm{~kg} / \mathrm{ha}$, respectively. Cv. Centa 105 yielded $1583 \mathrm{~kg} / \mathrm{ha}$. The cream-colored cvs. Climax, Sin Fibra and Zipper Cream yielded 1479, 1427, and $1829 \mathrm{~kg} / \mathrm{ha}$, respectively. The largest and heaviest individual seed was obtained from cv. B 54, while those of cv. Climax were the smallest. The largest number of pods per plants were obtained from cvs. Pequeño, Frijol Gordo, and Costa Rica while the least number of pods per plant were obtained from cvs. Sin Fibra, Zipper Cream and Climax. Cv. Sin Fibra produced the largest number of grains per pod. All cultivars seem to have good adaptability under the conditions prevailing in northwestern Puerto Rico.
\end{abstract}

\section{INTRODUCTION}

The cowpea (Vigna unguiculata) is a warm-season annual herbaceous legume which was produced and consumed in the past, but is now almost unknown in Puerto Rico. However, the dry grain averages 23 to $25 \%$ total protein, $57 \%$ carbohydrates, $1.3 \%$ fat and $3.5 \%$ minerals (3). Its protein is comparatively rich in lysine and tryptophan, amino acids which are usually deficient in cereal grains. Cowpeas with good management practices are as good or better producers than the field beans (Phaseolus vulgaris) $(1,2)$. They are tolerant to extended drought periods and are extremely tolerant to low soil pH. Spain et al. (6) obtained significant yield responses under the conditions prevailing at Carimagua, Colombia, on a soil with $\mathrm{pH} 4.3$, only to the first 0.5 tons/ha of lime increment. They noticed that cowpeas were more tolerant to high soil acidity than field beans. This evidence suggests that cowpeas may be a suitable crop for the acid Oxisols of the tropics. Also this crop will fit well into traditional mixed cropping systems.

'Manuscript submitted to Editorial Board Sept. 6, 1979.

${ }^{2}$ Associate Agronomist and Plant Breeder, Director of the Agricultural Experiment Station, respectively, Mayagüez Campus, Río Piedras, P.R. Dr. Carlos Cruz and Mr. Edgar Cardona, Associate Entomologist and Research Assistant, respectively, tested and evaluated the cultivars for insect damage. Dr. M. A. Lugo-López's valuable suggestions are deeply appreciated. 
The objective of this work was to evaluate high yielding materials and determine their adaptability to climatic conditions prevailing in northwestern Puerto Rico.

\section{MATERIALS AND METHODS}

The experiments were conducted at the Isabela Substation, located about $120 \mathrm{~m}$ above sea level. The mean annual maximum temperature is $29.4^{\circ} \mathrm{C}$ while the mean minimum temperature is $18.9^{\circ} \mathrm{C}$. The mean annual rainfall is about $1658 \mathrm{~mm}$ with showers from November to January and a dry spell generally extending from mid-January to April.

The soil is Coto, a Tropectic Haplorthox, clayey, kaolinitic, isohyperthermic (4). It has an exchange capacity of around 13 meq and $25 \% \mathrm{Ca}$ saturation. It is high in $\mathrm{Mn}$, low in $\mathrm{P}$ and with a $\mathrm{pH}$ of 4.8 .

The experiments were planted October 24, 27 and 19 of 1975, 1976 and 1978, respectively. Harvesting of dry pods was generally about 80 days after planting. The experiments followed partially balanced incomplete block designs with eight treatments (cultivars) replicated four times. The plots were $3.03 \times 3.03 \mathrm{~m}$ with $0.75 \mathrm{~m}$ alleys between plots. Each plot consisted of four rows $75 \mathrm{~cm}$ apart with plants spaced $30 \mathrm{~cm}$ within the row, for a total of 40 plants per treatment per replicate. The cultivars tested were Costa Rica, Pequeño, B 54, Sin Fibra, Zipper Cream, Climax, Centa 105 and Frijol Gordo.

The crop received a 10-10-10 fertilizer at the rate of $1121 \mathrm{~kg} / \mathrm{ha}$ at planting time. Crop protection was provided by spraying several times with Lannate ${ }^{3}$ at the rate of $2.47 \mathrm{qt} /$ ha plus Dithane M45 at the rate of $2.24 \mathrm{~kg} / \mathrm{ha}$. Supplemental irrigation was applied as needed.

Data were taken on number of plants per plot, weight of four plants, number of pods in the four plants, weight of seeds, weight of 10 pods, number of seeds in ten pods, weight of seed in the 10 pods, total weight for the plot and seed moisture. Data were accumulated for three years.

\section{RESULTS AND DISCUSSION}

The brown-colored cultivar B 54 was consistently the top yielder during the series of trials ranging from 1837 to $2402 \mathrm{~kg} / \mathrm{ha}$ for a 3-year average of $2197 \mathrm{~kg} / \mathrm{ha}$ (table 1). Yields from cvs. B 54, Pequeño and Costa Rica did not differ statistically in two of the three years; while yields of Pequeño, Costa Rica and Frijol Gordo were not significantly different during the 3 years. Pooled data from the 3 years showed that $\mathrm{cv}$. B 54 outyielded cv. Pequeño by $131 \mathrm{~kg} / \mathrm{ha}$ (not significant), cv. Costa Rica by $237 \mathrm{~kg} / \mathrm{ha}$ (significant), and cv. Frijol Gordo by $454 \mathrm{~kg} / \mathrm{ha}$ (significant).

\footnotetext{
${ }^{3}$ Trade names in this publication are used only to provide specific information. Mention of a trade name does not constitute a warranty of equipment or materials by the Agricultural Experiment Station of the University of Puerto Rico, nor is this mention a statement of preference over other equipment or materials.
} 
The latter is the cultivar preferred by most of the local farmers. B 54 has an average of 26.2 pods/plant with 12.03 seeds per pod (tables 2 and 3 ). The brown dry seeds (23.30 grams/100 seeds) are significantly larger than all other cultivars. (table 4). The plant is vigorous, slightly prostrate, with very few guides. Blooming took place about 54 days after planting. It is tolerant to disease and insect attacks (table 5) and is highly resistant to attacks by the bean leaf beetle Cerotoma ruficornis. Table 5 shows that pod infestation by the cowpea curculio, Chalcodermus ebeninus is low. Although counts of leafhopper of the genus Empoasca were relatively high (3.42 per leaflet 35 days after planting), foliar damage was not serious. Leafhopper counts dropped to less than one nymph per leaflet 50 days after planting.

Mean yields of the black "eye" cvs. Pequeño, Costa Rica and Frijol Gordo were over $1700 \mathrm{~kg} / \mathrm{ha}$ (table 1). The yield from cvs. Pequeño and

TABLE 1.-Dry yields ${ }^{1}(\mathrm{~kg} / \mathrm{ha})$ of eight cowpea cultivars from three crops planted on an Oxisol at the Isabela Substation, Isabela, P.R.

\begin{tabular}{lllll}
\hline \multirow{2}{*}{ Cultivars } & \multicolumn{3}{c}{ Yield for indicated crop years } & \multicolumn{1}{c}{$\begin{array}{c}\text { Adjusted } \\
\text { means- } \\
\text { 3 years }\end{array}$} \\
\cline { 2 - 4 } & $1975-76$ & $1976-77$ & $1978-79$ & $2197 \mathrm{a}$ \\
\hline B 54 & $2295 \mathrm{a}^{2}$ & $1837 \mathrm{a}$ & $2402 \mathrm{a}$ & $2066 \mathrm{a}, \mathrm{c}$ \\
Pequeño & $1991 \mathrm{a}, \mathrm{b}$ & $1695 \mathrm{a}, \mathrm{c}$ & $2007 \mathrm{~b}$ & $1960 \mathrm{~b}, \mathrm{c}$ \\
Costa Rica & $1970 \mathrm{a}, \mathrm{b}$ & $1586 \mathrm{a}, \mathrm{c}, \mathrm{d}$ & $2015 \mathrm{~b}$ & $1743 \mathrm{~d}, \mathrm{e}, \mathrm{f}$ \\
Frijol Gordo & $1768 \mathrm{~b}, \mathrm{c}$ & $1490 \mathrm{a}, \mathrm{c}, \mathrm{d}$ & $1752 \mathrm{~b}, \mathrm{c}$ & $1583 \mathrm{f}, \mathrm{g}$ \\
Centa 105 & $1494 \mathrm{c}$ & $1419 \mathrm{~b}, \mathrm{c}, \mathrm{d}$ & $1542 \mathrm{c}, \mathrm{d}$ & $1494 \mathrm{~g}$ \\
Climax & $1483 \mathrm{c}, \mathrm{d}$ & $1337 \mathrm{~b}, \mathrm{c}, \mathrm{d}$ & $1408 \mathrm{~d}$ & $1427 \mathrm{~g}$ \\
Sin Fibra & $1277 \mathrm{~d}$ & $1289 \mathrm{~b}, \mathrm{~d}$ & $1486 \mathrm{~d}$ & $1829 \mathrm{~b}, \mathrm{e}$ \\
Zipper Cream & $2061 \mathrm{a}, \mathrm{b}$ & $1289 \mathrm{~b}, \mathrm{~d}$ & $1837 \mathrm{~b}$ & \\
\hline
\end{tabular}

${ }^{1}$ Dry weight at $11 \%$ moisture.

${ }^{2}$ Means in any column followed by the same letters do not differ significantly at the $5 \%$ probability level.

Costa Rica did not differ statistically; however, both cultivars significantly outyielded Frijol Gordo. The three cvs. have smooth white coats with a rather large black "eye." This is the type of cowpea preferred by local consumers. All of them average over 30 pods/plant (table 2) with the number of seeds varying from 11 to 13 /pod (table 3). Mean dry seed weights were $13.41,14.32$ and 17.17 gram/100 seeds for cvs. Pequeño, Costa Rica, and Frijol Gordo, respectively (table 4). The cvs. are vigorous erect plants with violet pod tips. Blooming occurs at about 58, 53 and 50 days after planting in the case of Pequeño, Costa Rica, and Frijol Gordo, respectively. Plants suffered from moderate attacks by leafhoppers and bean leaf beetles and were slightly damaged by leafhoppers. The Pequeño pods were free of cowpea curculio damage (table 5). Frijol Gordo suffered extremely serious insect damage. 
TABLE 2.-Mean number of pods/cowpea plant from three crops planted on an Oxisol at the Isabela Substation, Isabela, P.R.

\begin{tabular}{llll}
\hline \multirow{2}{*}{ Cultivars } & \multicolumn{3}{c}{ Number of pods for indicated crop years } \\
\cline { 2 - 4 } & $1975-76$ & $1976-77$ & $1978-79$ \\
\hline B 54 & $28.53 \mathrm{a}, \mathrm{cc}^{1}$ & $21.88 \mathrm{c}, \mathrm{d}$ & $28.20 \mathrm{a}$ \\
Pequeño & $37.05 \mathrm{a}$ & $29.69 \mathrm{a}, \mathrm{b}, \mathrm{c}$ & $26.1 \mathrm{a}, \mathrm{b}$ \\
Costa Rica & $29.59 \mathrm{a}, \mathrm{c}$ & $35.31 \mathrm{a}$ & $27.69 \mathrm{a}, \mathrm{b}$ \\
Frijol Gordo & $35.10 \mathrm{a}$ & $30.88 \mathrm{a}, \mathrm{b}$ & $29.59 \mathrm{a}$ \\
Centa 105 & $28.90 \mathrm{a}, \mathrm{c}$ & $24.31 \mathrm{~b}, \mathrm{c}, \mathrm{d}$ & $24.16 \mathrm{a}, \mathrm{b}$ \\
Climax & $24.83 \mathrm{~b}, \mathrm{c}$ & $29,50 \mathrm{a}, \mathrm{b}, \mathrm{c}$ & $22.93 \mathrm{a}, \mathrm{b}$ \\
Sin Fibra & $21.16 \mathrm{~b}, \mathrm{c}$ & $21.63 \mathrm{c}, \mathrm{d}$ & $20.75 \mathrm{~b}$ \\
Zipper Cream & $27.05 \mathrm{a}, \mathrm{c}$ & $18.94 \mathrm{~d}$ & $23.51 \mathrm{a}, \mathrm{b}$ \\
\hline
\end{tabular}

${ }^{1}$ Means in any column followed by the same letter do not differ significantly at the $5 \%$ prohability level.

TABLE 3.-Number of seeds in ten pods from eight cowpea cultivars from three crops planted on an Oxisol at the Isabela Substation, Isabela, P.R.

\begin{tabular}{lccc}
\hline \multirow{2}{*}{ Cultivars } & \multicolumn{3}{c}{ Number of grains in 10 pods for indicated years } \\
\cline { 2 - 4 } & $1975-76$ & $1976-77$ & $1978-79$ \\
\hline B 54 & $115.5 \mathrm{a}, \mathrm{c}$ & $109.3 \mathrm{~b}, \mathrm{~d}$ & $136.1 \mathrm{a}, \mathrm{b}, \mathrm{c}$ \\
Pequeno & $118.6 \mathrm{a}, \mathrm{c}$ & $116.6 \mathrm{~b}, \mathrm{c}, \mathrm{d}$ & $130.0 \mathrm{a}, \mathrm{b}, \mathrm{c}$ \\
Costa Rica & $114.2 \mathrm{a}, \mathrm{c}$ & $119.0 \mathrm{~b}, \mathrm{c}, \mathrm{d}$ & $114.5 \mathrm{~b}$ \\
Frijol Gordo & $108.8 \mathrm{~b}$ & $95.8 \mathrm{~b}, \mathrm{~d}$ & $121.6 \mathrm{~b}, \mathrm{c}$ \\
Centa 105 & $117.0 \mathrm{a}, \mathrm{c}$ & $122.0 \mathrm{a}, \mathrm{c}, \mathrm{d}$ & $119.4 \mathrm{~b}$ \\
Climax & $128.5 \mathrm{a}, \mathrm{c}$ & $138.7 \mathrm{a}$ & $150.2 \mathrm{a}$ \\
Sin Fibra & $123.3 \mathrm{a}, \mathrm{c}$ & $132.2 \mathrm{a}, \mathrm{c}$ & $142.5 \mathrm{a}$ \\
Zipper Cream & $132.9 \mathrm{a}$ & $129.7 \mathrm{a}, \mathrm{c}$ & $142.5 \mathrm{a}, \mathrm{c}$ \\
\hline
\end{tabular}

${ }^{1}$ Means in any column followed by the same letters do not differ significantly at the $5 \%$ probability level.

TABLE 4.-Mean weight of 100 dry cowpea grains from eight cultivars planted for three crop years on an Oxisol at the Isabela Substation, Isabela, P.R.

\begin{tabular}{lccc}
\hline \multirow{2}{*}{ Cultivars } & \multicolumn{3}{c}{ Weight for indicated crop years } \\
\cline { 2 - 4 } & $1975-76$ & $1976-77$ & $1978-79$ \\
\hline B 54 & $23.17 \mathrm{a}$ & $22.61 \mathrm{a}$ & $24.11 \mathrm{a}$ \\
Pequeño & $15.06 \mathrm{~d}, \mathrm{e}, \mathrm{f}$ & $11.80 \mathrm{c}$ & $13.38 \mathrm{~d}$ \\
Costa Rica & $15.19 \mathrm{~d}, \mathrm{e}$ & $13.96 \mathrm{c}$ & $13.82 \mathrm{~d}$ \\
Frijol Gordo & $17.85 \mathrm{c}$ & $16.58 \mathrm{~b}$ & $17.07 \mathrm{c}$ \\
Centa & $15.57 \mathrm{~d}$ & $13.16 \mathrm{c}$ & $15.56 \mathrm{c}, \mathrm{d}$ \\
Climax & $12.10 \mathrm{e}$ & $12.40 \mathrm{c}$ & $13.12 \mathrm{~d}$ \\
Sin fibra & $16.58 \mathrm{c}, \mathrm{d}$ & $13.07 \mathrm{c}$ & $13.85 \mathrm{~d}$ \\
Zipper Cream & $19.78 \mathrm{~b}$ & $18.22 \mathrm{~b}$ & $20.67 \mathrm{~b}$ \\
\hline
\end{tabular}

${ }^{1}$ Means in any column followed by the same letters do not differ significantly at the $5 \%$ probability level. 
The black cv. Centa 105 yielded an average of $1583 \mathrm{~kg} / \mathrm{ha}$ for the three crops (table 1), which was not statistically different from the yields of Frijol Gordo, the cultivar used as control. Centa 105 averaged 25.8 pods per plant with 12 seeds/pod (table 2 and 3). The dry seeds are black (table 4) and of medium size (14.76 g/100 seeds). Dry seeds of Centa 105 are similar to small dry field beans. This characteristic is valuable since they can thus be marketed as a substitute for dry black beans. The plant is vigorous, with few guides, and blooms about 53 days after planting. Resistance to insects and diseases was noted. An average of only 0.85 leafhopper nymph/leaflet was detected 50 days after planting, and cowpea curculio damage was very low at that stage (table 5).

Mean yields of the cream-colored cvs. Climax, Sin Fibra and Zipper Cream were 1479, 1427 and $1829 \mathrm{~kg} /$ ha respectively. These are considered acceptable yields. However, these cultivars have a different type of seed:

TABLE 5.-Relative infestation by insects of eight cowpea cultivars planted on an Oxisol at the Isabela Substation, Isabela, P.R.

\begin{tabular}{|c|c|c|c|c|c|}
\hline \multirow{2}{*}{ Cultivar } & \multirow{2}{*}{\multicolumn{2}{|c|}{$\begin{array}{c}\begin{array}{c}\text { Average leafhopper nymph/ } \\
\text { leaflet }\end{array} \\
\frac{\text { Days after planting }}{35} \quad 50\end{array}$}} & \multicolumn{3}{|c|}{ Evaluation for visual damage ${ }^{1}$} \\
\hline & & & \multirow{2}{*}{$\begin{array}{c}\text { Empoasca } \\
\text { spp } \\
1.62\end{array}$} & \multirow{2}{*}{$\begin{array}{c}\text { Cerotoma } \\
\text { ruficornis } \\
1.25\end{array}$} & \multirow{2}{*}{$\begin{array}{c}\begin{array}{c}\text { Chalcodermus } \\
\text { ebeninus }\end{array} \\
1.73\end{array}$} \\
\hline B 54 & 3.42 & 0.95 & & & \\
\hline Pequeño & 3.05 & 1.17 & 1.87 & 2.50 & 0.00 \\
\hline Costa Rica & 3.00 & 1.17 & 1.75 & 1.12 & 1.79 \\
\hline Frijol Gordo & 4.25 & 1.30 & 2.12 & 1.62 & 2.38 \\
\hline Centa 105 & 2.52 & 0.85 & 1.87 & 1.50 & 0.60 \\
\hline Climax & 3.72 & 1.12 & 1.87 & 2.37 & 1.06 \\
\hline Sin Fibra & 3.15 & 2.27 & 2.00 & 1.50 & 1.71 \\
\hline Zipper Cream & 2.27 & 1.15 & 2.37 & 2.00 & 0.92 \\
\hline
\end{tabular}

${ }^{1}$ Based on a $1-5$ scale; where $1=$ normal, $5=$ heavy damage.

cream-colored without a pronounced "eye." Cv. Climax dry seeds are round and small (12.54 gms/100 seeds). Cv. Sin Fibra dry seeds are kidney-shaped and medium-sized (14.50 gms/100 seeds). Cv. Zipper Cream dry seeds are round and relatively large (19.56 gram/100 seeds) (table 4). The three cultivars had the lowest average number of pods/ plant (21-23) but the highest number of seeds/pod (over 13) (table 2). In general, all three cultivars suffered moderate attacks from insects (table 5). Plants of cvs. Climax and Zipper Cream are vigorous and of prostrate growth habit; Zipper Cream has guides, but Sin Fibra grows erect with only a few guides.

This study indicates that cultivar B 54 seems to be the best suited for commercial production in Oxisols under the conditions prevailing in northwestern Puerto Rico. It produces consistently higher yields (table 
1) or significantly heavier seeds (table 4) and is a vigorous plant, fairly resistant to insects and diseases. Cultivars Pequeño, Costa Rica and Frijol Gordo, preferred by local consumers, also appear to be promising for northwestern Puerto Rico.

The possibilities of Centa 105 for a limited specialty market, should be considered because of its black and medium-sized seeds, which can be used as a substitute for small dry black beans.

The yields of cowpeas, as measured in the three experiments herein reported, compare very favorably with yields of dry field beans (Phaseolus vulgaris) grown under the same conditions $(1,2,5)$. Their high protein content, their richness in lysine and tryptophan, as well as the generally vigorous growth habit, make the cowpea an attractive and useful crop for the tropics. Furthermore, because of their recognized. tolerance to drought and to extremely high soil acidity, as well as their capacity to fix atmospheric nitrogen, the cowpeas can be valuable in crop rotation in the weathered, highly leached, extremely acid and relatively infertile Oxisols of the humid tropics.

\section{RESUMEN}

Se estudió por tres años el comportamiento de ocho cultivares de frijoles (Vigna unguiculata) en un suelo Coto arcilloso (Oxisol) en la Subestación Experimental de Isabela. Los rendimientos más altos se obtuvieron con la cv. B 54 (2197 kg/ha). Esta es un frijol de testa color marrón. Las cvs. Pequeño, Costa Rica y Frijol Gordo del tipo "Ojinegros" le siguieron con rendimientos de 2066,1960 y $1743 \mathrm{~kg} / \mathrm{ha}$, respectivamente. La cv. Centa 105, de testa negra, produjo $1583 \mathrm{~kg} / \mathrm{ha}$. Las de testa crema Sin Fibra, Zipper Cream y Climax, produjeron sobre 1200 $\mathrm{kg} / \mathrm{ha}$. Las semillas más grandes y pesadas se obtuvieron de la cv. B 54 mientras que las más pequeñas fueron las de cv. Climax. Todas las cultivares parecen adaptarse bien a las condiciones prevalecientes en el noroeste de Puerto Rico.

\section{LITERATURE CITED}

1. Badillo-Feliciano, J., Lugo-López, M. A. and Scott, T. W., 1978. Effect of planting distance on yield and agronomic characteristics of red kidney and white bean in an Oxisol, J. Agri. Univ. P.R. 62 (2): 145-8.

2. González-Ríos, P. and Riollano, A., 1951. El mejoramiento de la habichuela blanca del país (Phaseolus vulgaris) por medio de la selección, Esta. Exp. Agri. Univ. P.R. Bol. 94.

3. Litzemberger, S. C. 1974. Cowpea. In guide for field crops in the tropics and subtropics. Office of Agriculture Technical Assistance Bureau, AID, Washington, D.C. Chap. 12: $109-14$.

4. Lugo-López, M. A. and Rivera, L. H., 1976. Taxonomic classification of the soils of Puerto Rico, Agri. Exp. Stn. Univ. P.R. Bull. 245. 
5. Badillo-Feliciano, J. and Calduch, L., 1977. Response of native white beans, Phaseolus vulgaris, to various N levels in an Oxisol, J. Agri. Univ. P.R. 61 (4): 43842.

6. Spain, J. M., Francis, C. A., Howeler, R. H. and Calvo, F., 1974. Diferencias entre especies y variedades de cultivos y pastos tropicales en la tolerancia a la acidez del suelo. Manejo de suelos de la América Tropical. Elemer Boernemiza y A. Alvarado, Ed. Soil Sci. Dep. N. C. State Univ., Raleigh, N.C. 